\title{
Penguatan Kelembagaan Rukun Tetangga dan Rukun Kampung (RT/RW) Di Kelurahan Rintis Kecamatan Lima Puluh Kota Pekanbaru
}

\author{
Sulaiman Zuhdi ${ }^{1}$, Adia Ferizko ${ }^{2}$; Pebriana Melinda ${ }^{3}$
}

\begin{abstract}
ABSTRAK
Salah satu mitra pemerintah adalah Rukun Tetangga (RT) dan Rukun Warga (RW). RT / RW berfungsi sebagai pengkoordinasi antara warga, jembatan antara aspirasi sesama masyarakat dengan pemerintah daerah, melakukan mediasi penyelesaian masalah masyarakat yang dihadapi warga, sementara tugasnya antara lain membantu menjalankan tugas Kementerian kepada masyarakat. Pemerintah Kota, menjaga keharmonisan hidup, menyusun rencana dan melaksanakan pembangunan dengan mengembangkan aspirasi dan komunitas swadaya murni. Dari tugas dan fungsi RT / RW di atas dapat diketahui bahwa itu merupakan tugas yang vital. RT / RW adalah lembaga yang layak berhubungan langsung dengan publik, mereka adalah mulut dan telinga Pemerintah yang memiliki fungsi sebagai penyampai dan kebijakan Pemerintah sebagai penerima pertama dari aspirasi masyarakat. Pemerintah daerah telah mengeluarkan peraturan untuk Wilayah Kota Pekanbaru nomor 12 tahun 2002 tentang RT / RW. Namun, jika dilihat dari keberadaan kelembagaan RT / RW di kelurahan yang dirintis dalam menjalankan tugas dan fungsi yang belum sepenuhnya. Indikator yang terlihat belum sepenuhnya Ketua RT / RW akan mengetahui dan memahami tugas, fungsi dan tanggung jawab serta program yang dikelola pemerintah, struktur organisasi RT / RW yang belum berfungsi dengan baik, serta kurangnya koordinasi dan kerjasama yang baik antara administrator RT / RW dan bangsal pemerintah. Dengan kondisi seperti itu sangat berpengaruh terhadap kinerja kelembagaan RT / RW.
\end{abstract}

Kata Kunci : penguatan; institusional; pemerintahan; RT/RW

\begin{abstract}
One of the partners of Government wards was Jiran (RT) and Pillars of the citizens (RW). $R T / R W$ functions as pengkoordinasi between the citizens, the bridge between the aspirations of their fellow communities with local governments, mediate the resolution of societal problems faced by citizens, while his duties among others help run the task of Ministry to the community the responsibility of City Government, maintain harmony life, devised a plan and execute development with developing aspirations and pure self-help community. Of the duties and functions of the RT/RW above can be known is vital. RT/RW is viable institutions deal directly with the public, they are the mouth and ears of the Government which has a function as a Messenger and Government policies as the first recipient of the aspirations of the
\end{abstract}

\footnotetext{
${ }^{1}$ Universitas Lancang Kuning. Email : sulaiman@unilak.ac.id

${ }^{2}$ Universitas Lancang Kuning

${ }^{3}$ Universitas Lancang Kuning
} 
community. The local Government has issued a regulation to Pekanbaru City Area number 12 of the year 2002 about RT/RW. However, if seen from the existence of institutional RT/RW in kelurahan Pioneered in carrying out the tasks and functions have not been fullest. Visible indicators is not yet fully Chairman RT/RW will know and understand the tasks, functions and responsibilities as well as the Government-run program, organizational structure RT/RW that hasn't been functioning properly, and the lack of coordination and good cooperation between administrators a RT/RW and Government wards. With such a condition very influential towards the institutional performance of the RT/RW.

Keyword : strengthening; institutional; government; RT/RW.

\section{PENDAHULUAN}

Organisasi Rukun Tetangga (RT) dan Rukun Warga (RW) merupakan mitra pemerintah kelurahan. Menurut Peraturan Menteri Dalam Negeri (Permendagri) No. 5 tahun 2007, RT/RW adalah lembaga yang dibentuk melalui musyawarah masyarakat setempat dalam rangka pelayanan pemerintahan dan kemasyarakatan yang ditetapkan oleh Pemerintah Desa atau Lurah. RT/RW mempunyai fungsi sebagai pengkoordinasi antar warga, jembatan aspirasi antar sesama masyarakat dengan pemerintah daerah, menjadi penengah penyelesaian masalahmasalah kemasyarakatan yang dihadapi warga, sedangkan tugas RT/RW antara lain membantu pemerintah dalam tugas-tugas pelayanan kepada masyarakat yang menjadi tanggung jawab pemerintah kota, memelihara kerukunan hidup warga, menyusun rencana dan melak-sanakan pembangunan dengan mengem-bangkan aspirasi dan swadaya murni masyarakat.

Menurut Peraturan Daerah (Perda) Kota Pekanbaru No. 12 Tahun 2002 tentang RT/RW pasal 3, menyebutkan RT/RW dibentuk dengan maksud dan tujuan sebagai berikut :

1. Memelihara dan melestarikan nilai-nilai kehidupan masyarakat yang didasarkan kepada kegotong royongan.
2. Meningkatkan kelancaran pelaksanaan tugas-tugas pemerintahan, perencanaan dan pelaksanaan pembangunan serta kemasyarakatan.

3. Menghimpun seluruh potensi swadaya dimasyarakat dalam rangka meningkatkan kesejahteraannya.

RW sesuai Perda Kota Pekanbaru No. 12 tahun 2002 pasal 7 menyatakan bahwa :

1. Membantu terwujudnya kehidupan masyarakat berdasarkan Pancasila dan Undang-undang Dasar 1945.

2. Menggerakkan Gotong Royong, swadaya dan partisipasi masyarakat.

3. Membantu terciptanya ketentraman, dan ketertiban dalam masyarkat

4. Membantu terciptanya kebersihan, dan keindahan lingkungan.

5. Membatu menyebarluaskan, dan mengamankan setiap program Pemerintah Daerah.

6. Menjembatani hubungan antar sesama anggota masyarakat dan Pemerintahan Daerah.

7. Membantu menciptakan serta memelihara kelestarian lingkungan hidup.

Dilihat dari tugas dan fungsi RT/RW tersebut, diatas dapat diketahui amatlah 
penting. Organisasi RT/RW adalah suatu lembaga kemasyarakatan yang ada di desa/kelurahan yang berhubungan langsung dengan masyarakat, mereka mempunyai fungsi sebagai perantara bagi penyampaian kebijakan, program, dan kegiatan-kegiatan pemerintah kelurahan, daerah maupun nasional dan juga sebagai lembaga pertama penerima aspirasi dan kepentingan masyarakat sehingga mereka lebih memahami tentang permasalahan yang ada di masyarakat.

Sebagai lembaga yang ada di desa/kelurahan, RT/RW harus berperan aktif dalam mendukung visi, misi dan tujuan pembangunan pemerintah di daerah. RT/RW harus mampu menjadi dinamisator dalam rangka meningkatkan partisipasi masyarakat, peningkatkan pelayanan pemerintah kelurahan, pembangunan, dan pemberdayaan di masya rakat. Selain itu kelembagaan RT/RW juga berperan dalam penataan lingkungan hidup, menjadi fasilitator yang bisa menjaga komunikasi dan harmonisasi kebijakan, program dan kegiatan dari pemerintah kelurahan kepada masyarakat serta memberikan masukan kepada pemerintah secara objektif, optimal dan berkesinambungan sesuai prosedur dan mekanisme yang berlaku.

Didalam Permendagri No. 7 tahun 1983, pasal 1 menyebutkan bahwa RT/RW adalah organisasi masyarakat yang diakui dan dibina oleh pemerintah untuk memelihara dan melestarikan nilai-nilai kehidupan masyarakat diIndonesia yang didasarkan kepada kegotongroyongan dan kekeluargaan serta untuk membantu meningkatkan kelancaran pelaksanaan tugas-tugas pemerintahan, pembangunan dan kemasyarakatan di Desa/ Kelurahan.

Pemerintah harus berupaya maksimal dalam peningkatan kapasitas kelembagaan RT/RW karena dengan kapasitas yang mumpuni mereka mampu menjalankan peran dan fungsi sebagai lembaga kemasyarakatan yang mampu menyampaikan kebijakan pemerintah kemasyarakat dan mampu menyerap aspirasi masyarakat untuk disampaikan kepada pemerintah sebagai upaya optimalisasi pembangunan masyarakat dan pembangunan di kelurahan melalui bimbingan dan pelatihan serta pembinaan kepada pengurus RT/RW yang berhubungan dengan birokrasi, tata laksana pemerintah, administrasi, hingga sosialisasi peraturan dan kebijakan dari pemerintah.

Program-program pemerintah pusat juga sudah saatnya harus melibatkan langsung para pengurus RT/RW sebagai operator/petugas di lapangan, tentunya dengan memberikan pelatihan-pelatihan dan bimbingan intensif yang diberikan terlebih dahulu kepada mereka. Sensus penduduk, sensus ekonomi, sensus pertanian, penyuluhan agama, kesehatan bahkan pendampingan keluarga harapan atau program lainnya sudah saatnya melibatkan mereka bahkan menjadikan mereka sebagai petugas langsung, hal ini sangat berdampak positif bagi peningkatan sumberdaya manusia serta akan memberikan informasi yang lebih akurat kepada pemerintah tentang kondisi terkini masyarakat karena merekalah yang setiap hari bersinggungan langsung dengan masyarakat.

Dari penjelasan diatas menunjukkan bahwa betapa kompleks dan beratnya tugastugas yang dipikul oleh RT/RW, apalagi dalam kondisi masyarakat yang sangat dinamis dan cenderung arogan saat ini, sehingga terkadang disuatu daerah tertentu mengalami kesulitan dalam mencari figur yang mampu dan layak untuk mengabdi sebagai ketua RT/RW.

Kelurahan Rintis merupakan kelurahan yang ada di Kecamatan Lima puluh Kota Pekanbaru dengan jumlah penduduk lebih kurang 6.722 jiwa. Jumlah RT sebanyak 29 
buah dan RW sebanyak 8 buah. Wilayah kelurahan ini sangat strategis berada dipusat kota Pekanbaru yang tentunya akan banyak mengalami dinamika sosial dan permasalahan yang biasa terjadi kota. Dari hasil pengamatan atau wawancara singkat yang dilakukan penulis terhadap kinerja RT/RW di Kelurahan Rintis, menunjukkan bahwa :

1. Belum sepenuhnya ketua RT/RW mengetahui dan memahami akan tugas, fungsi dan tanggungjawabnya

2. Struktur organisasi RT/RW yang belum menjalankan fungsinya dengan baik, sehingga ketua RT/RW bekerja sendiri tanpa adanya bantuan dari pengurus lain. Hal inilah yang mengakibatkan ketua RT/RW hanya simbol saja ditengahtengah masyarakat alias tukang teken surat pengantar.

3. Kurangnya koordinasi dan kerjasama pengurus RT/RW dan pemerintah kelurahan sehingga program kegiatan pemerintah kelurahan kurang terlaksana dengan baik.

4. Kurangnya pembinaan dari pemerintah seperti pelatihan yang berhubungan dengan birokrasi, tata laksana dan administrasi pemerintah.

Adapun tujuan dari penelitian ini adalah untuk memberikan gambaran tentang penguatan kelembagaan RT/RW di kelurahan Rintis Kecamatan Lima Puluh Kota Pekanbaru serta faktor-faktor penghambat.

\section{METODE PENELITIAN}

Metode penelitian ini adalah deskriptif dengan pendekatan kualitatif. Penggunaan kualitatif dilaksanakan melalui observasi, interview atau wawancara dan studi pustaka, yaitu mengambil data dari sejumlah buku, literatur, internet, maupun perundangundangan. Dalam menganalisa data dan informasi yang diperoleh, penulis melakukan langkah-langkah mereduksi data, klasifikasi data dan pengolahan data secara kualitatif. Dalam tahapan ini setiap data diberikan pengertian sehingga mudah dipahami untuk mendapatkan kesimpulan akhir.

\section{HASIL DAN PEMBAHASAN}

\section{Penguatan Kelembagaan RT/RW}

Dalam penelitian ini, penulis menyoroti tentang penguatan kelembagaan RT/RW dilihat dari sumber daya manusia, organisasi dan jaringan kerja sesuai dengan teori D. Edge dalam Mutiarin, 2014. Untuk lebih jelasnya dapat diuraikan sebagai berikut :

\section{a. Sumber Daya Manusia}

Dalam Penguatan kelembagaan RT/RW diperlukan sumberdaya manusia (SDM) yang handal sebagai pelaksana penguatan kelembagaan, karena SDM memegang peran penting dalam suatu organisasi.

\section{Pemilihan/rekrutmen $R T / R W$}

Pemilihan/rekrutmen merupakan suatu proses mendapatkan dan menarik pelamar yang dianggap mampu untuk suatu pekerjaan. Proses rekrutmen RT/RW melalui musyawarah dan mufakat warga dan hasilnya akan ditetapkan melalui surat keputusan Lurah setelah mendapatkan pengesahan Camat atas nama Walikota.

Pekerjaan menjadi pengurus RT/RW merupakan pekerjaan sosial/pengabdian, yang pada sebagian orang kurang menarik. Banyak masyarakat beranggapan bahwa menjadi pengurus RT/RW akan membuat mereka sibuk dan menghabiskan banyak waktu, karena 
bayaran yang diterima tidak sesuai dengan apa yang sudah mereka kerjakan. Oleh karena itu setiap periode kepengurusan RT/RW berakhir akan sulit untuk mencari penggantinya. Sehingga tidak jarang dijumpai pengurus RT/RW yang terpilih orangnya itu-itu saja. Padahal berdasarkan Perwako masa kepengurusan RT/RW itu hanya dua periode saja.

Dari penjelasan diatas, penulis mencoba melakukan wawancara singkat dengan Lurah Rintis Bapak Adri Hidayat Putra, S.STP tanggal 18 Pebruari 2019 yang menyatakan bahwa :

“... kalau di wilayah ini masyarakat jarang yang mau menjadi ketua RT/RW karena kesibukan mereka masing-masing untuk mencari nafkah. Selain itu disini juga banyak permasalahan sosial yang terjadi, karena ini daerah kota dan termasuk rawan kejahatan, jadi mereka tidak mau berurusan dan repot...”.

Dari pernyataan Lurah tersebut tergambar bahwasanya masyarakat kurang berminat menjadi pengurus RT/RW. Inilah yang jadi penyebab susahnya untuk mendapatkan sumber daya yang memadai didalam menjalankan tugas-tugas RT/RW sebagai mitra pemerintah kelurahan dan dalam pembinaan kehidupan bermasyarakat.

Dari hasil wawancara diatas dapat diketahui bahwasanya untuk mencari pengurus RT/RW yang handal dan memadai dalam melaksanakan tugas-tugas RT/RW sangat sulit. Ini bukan berarti tidak ada SDM yang cakap, namun lebih kepada kesadaran masyarakat yang kurang peduli terhadap pentingnya kelembagaan RT/RW. Inilah dilema yang dihadapi pemerintah, terlebih dalam kehidupan masyarakat heterogen yang ada diperkotaan yang tingkat dinamika persoalan sosial, ekonomi dan budaya yang tinggi, maka peran dan fungsi kelembagaan RT/RW ini sangat dibutuhkan untuk dapat menjadi penghubung antara masyarakat dan pemerintah.

\section{Sumber daya yang mengikuti pelatihan}

Bagi suatu organisasi, sumber daya manusia berkualitas memegang peranan yang sangat penting, begitu juga dengan kelembagaan RT/RW agar dapat menjalankan tugas-tugas RT/RW dengan baik.Untuk itu pemerintah kelurahan perlu melakukan usaha yang terencana untuk dapat meningkatkan pengetahuan dan kemampuan kerja dari pengurus RT/RW. Peningkatan pengetahuan dan kemampuan kerja pengurus RT/RW bisa dilakukan melalui pendidikan, bimbingan dan pelatihan yang dapat meningkatkan kinerja dari pengurus RT/RW sehingga mereka dapat melaksanakan tugas dan tanggungjawabnya dengan baik.

Dari wawancara dengan ketua forum RT/RW kelurahan Rintis tanggal 18 Pebruari 2019 mengatakan bahwa :

“... hampir 2 tahun saya menjabat ketua forum RT/RW disini belum pernah RT/RW dikumpulkan dan diberi pembekalan atau pelatihan tentang ketugasan serta perencanaan pembangunan...”

Dari hasil wawancara diatas dapat disimpulkan bahwasanya pemerintah kota Pekanbaru belum pernah memberikan pembinaan seperti pelatihan dan workshop bagi pengurus RT/RW sehingga kemampuan mereka dalam menjalankan tugas dan fungsinya tentu akan mengalami kendala dan masalah.

\section{b. Organisasi}

\section{Struktur organisasi}

Struktur organisasi menggambarkan bagaimana organisasi itu mengatur dirinya sendiri, bagaimana mengatur hubungan antar orang dan antar kelompok. Dengan adanya 
struktur organisasi, maka pembagian kerja dan fungsi yang berbeda dapat dikoordinasikan dengan baik. Jadi struktur organisasi merupakan komponen penting yang harus ada dalam suatu organisasi yang memuat tentang pembagian tugas dan tanggungjawab masingmasing orang sehingga tidak terjadi tumpang tindah atau overlop wewenang dan tanggungjawab dari anggota.

RT/RW sebagai suatu organisasi masyarakat yang keberadaannya diakui dan dibina oleh pemerintah, tentu harus memiliki struktur organisasi dan legalitas yang diberikan oleh pemerintah. Untuk itu kelembagaan RT/RW harus tercatat di pemerintahan desa/kelurahan dan memiliki surat keputusan kepengurusan lembaga yang dikeluarkan oleh Lurah dan mendapat pengesahkan dari Camat. Dari wawancara dengan ketua forum RT/RW kelurahan Rintis mengenai legalitas dan struktur organisasi RT/RW didapat :

“...dilihat dari struktur kepenguruan RT/RW yang ada belum bekerja dengan baik, jadi RT/RW bekerja sendirian tanpa ada yang membantu. Jadi Kalau RT tidak ada maka masyarakat yang ingin berurusan harus menunggu sampai RT ada. Kalau untuk legalitas semua RT/RW sudahmendapat surat pengangkatan...”

Dari hasil wawancara diatas dapat disimpulkan bahwasanya kepengurusan RT/RW sudah terbentuk dan sudah mendapatkan legalitas dari Lurah, namun kepengurusan yang ada belum dapat menjalan fungsinya dengan baik. Hal ini disebabkan kepengurusan yang terbentuk belum dapat menjalankan fungsinya dengan baik, sehingga hal ini juga dapat mempengaruhi kinerja dari RT/RW dalam melayani masyarakat.

\section{Tugas dan Tanggungjawab}

RT/RW sebagai mitra kelurahan tentunya mempunyai peranan yang penting dalam pemerintahan dan pembangunan di Kelurahan, dimana organisasi RT/RW merupakan jembatan yang dapat menghubungkan kepentingan masyarakat dengan pemerintah kelurahan. Untuk itu RT/RW dituntut untuk dapat melayani kepentingan masyarakat dalam bentuk apapun terutama pelayanan kepentingan masyarakat dan pembangunan di Kelurahan.

Jika dilihat pelayanan yang sering mengalami masalah di Kelurahan Rintis adalah masalah kependudukan yaitu masyarakat sering mengalami kesulitan dalam hal kepengurusan administrasi kependudukan, misalnya dalam kelengkapan berkas pengurusan KTP, KK, dll. Seperti yang disampaikan oleh Kasi Pemerintahan Kelurahan Rintis berikut kutipannya :

“...untuk masalah pengurusan berkas kependudukan harus ada surat pengantar dari RT/RW dimana masyarakat berdomisili, namun yang menjadi kendala kadang-kadang masyarakat tidak tahu sehingga urusannya menjadi lama...”

Dari pernyataan tersebut tergambar bahwasanya peran RT/RW sebagai garda terdepan dalam pengurusan administrasi kependudukan dikelurahan. Oleh karena itu penting bagi RT/RW untuk memahami tugas dan tanggungjawab dalam melayani masyarakatnya. Oleh karena itu, sebaiknya RT/RW bisa mensosialisasikan kebijakan, peraturan, dan program dari pemerintah kelurahan kepada masyarakat yang ada di RWnya.

Dari hasil wawancara diatas dapat dilihat bahwasanya RT/RW sudah cukup baik dalam melaksanakan tugas dan tanggungjawabnya namun harus mendapat dukungan dari masyarakat yang membutuhkan pelayanan 
RT/RW, sehingga peran dan fungsi RT/RW dapat berjalan dengan baik sebagai penghubung antara pemerintah kelurahan dan masyarakat sesuai dengan Perwako Pekanbaru No. 12 tahun 2002 pasal 7.

\section{c. Jaringan Kerja (Network)}

RT/RW adalah suatu lembaga yang dibentuk dan dipilih oleh masyarakat melalui musyawarah dan diangkat oleh Lurah. Oleh karena itu RT/RW tidak termasuk didalam struktur pemerintahan kelurahan sehingga tidak ada rentang kendali diantara mereka. Posisi RT/RW hanya sebagai mitra kerja pemerintahan kelurahan bukan antara atasan dan bawahan.

\section{Koordinasi}

Koordinasi disini maksudnya adalah kemampuan suatu organisasi untuk dapat saling bekerjasama dalam mencapai tujuan secara efisien dan efektif. Tujuan disini adalah bagaimana menyatukan tujuan RT/RW dengan keinginan masyarakat yang dilayani. Yang terpenting dalam koordinasi ini adalah terjalinnya komunikasi dua arah antara pengurus RT/RW dengan masyarakat, agar masing-masing pihak mengetahui perkembangan informasi pembangunan dan pemerintahan di kelurahan Rintis.

Dengan terjalinnya koordinasi yang baik antara pengurus RT/RW dengan masyarakat serta pemerintah kelurahan, maka diharapkan partisipasi masayarakat dalam program dan kegiatan pemerintah dapat lebih meningkat sehingga dapat menciptakan rasa kebersamaan dan kegotongroyongan diantara masyarakat.

Seperti yang diutarakan oleh Ketua forum RT/RW Kelurahan Rintis yang menyatakan :

“...kalau dari segi komunikasi dan koordinasi antara RT/RW dengan masyarakat sudah terjalin dengan baik. Ini bias dilihat dari partisipasi masyarakat dalam mendukung program pemerintah, misalnya dalam hal kegiatan gotong royong, kegiatan keagamaan dan kegiatan social lainnya. Masyarakat cukup peduli dengan kegiatan seperti itu..”.

Dari penjelasan diatas dapat disimpulkan bahwa kordinasi yang terjalin selama ini sangat baik sehingga ini dapat menjadi modal social bagi pemerintah kelurahan Rintis dalam melaksanakan dan mensukseskan program dan kegiatan-kegiatan pemerintah di Kelurahan Rintis.

\section{Aktivitas Organisasi}

Fungsi RT/RW merupakan jembatan yang menghubungkan antara masyarakat dengan pemerintah kelurahan. Untuk itu RT/RW harus bisa menjalankan tugas dan tanggungjawabnya dengan cara membuka peluang kegiatan yang berkaitan langsung dengan masyarakat. RT/RW harus aktif menampung seluruh aspirasi dari masyarakatnya untuk bisa disampaikan kepada pemerintah kelurahan. Begitu juga pemerintah kelurahan harus bisa menjalin komunikasi dan koordinasi dengan pengurus RT/RW, sehingga apa yang menjadi program kegiatan pemerintah dapat berjalan dengan baik.

Dengan harmonisnya hubungan antara RT/RW dengan masyarakat dan pemerintah maka diharapkan partisipasi dari masyarakat akan meningkat juga, karena masyarakat akan mengetahui tujuan dan sasaran dari pada kegiatan itu adalah untuk kepentingan dan kesejahteraan mereka sendiri.

Hubungan yang harmonis ini harus tetap terjaga, karena kalau tidak maka dikawatirkan akan terjadi konflik yang pada akhirnya akan merugikan masyarakat dan pemerintah, karena semua yang telah direncanakan dan diprogram 
oleh pemerintah tidak akan dapat berjalan sebagaimana mestinya.

Dilihat dari aktivitas organisasi RT/RW di kelurahan Rintis sudah dapat menjalin kerjasama dan mengakomodir keinginan dari masyarakatnya, misalnya saja dalam bidang perekonomian, dikelurahan Rintis telah terbentuk perkumpulan pedagang bakso yang telah dibina dan diberi bantuan dalam pengembangan usahanya, juga ada pelatihan menjahit bagi masyarakat yang ingin belajar menjahit. Dalam bidang organisasi masyarakat terlibat aktif dalam kegiatan pemerintah kelurahan seperti organisasi pemberdayaan masyarakat, dibidang social kemasyarakatan masyarakat aktif dalam kegiatan kematian, gotong royong dan hari besar nasional.

Seperti yang disampaikan oleh Sekretaris Lurah Rintis yang mengatakan bahwa :

“... dengan terlibatnya masyarakat dalam kegiatan pemerintah, maka akan membantu keberhasilan pelaksanaan tugas-tugas pemerintah kelurahan, dan masyarakat akan mendapatkan manfaat dari pada kegiatan tersebut, jadi kita saling bekerjasama...”.

Dari wawancara diatas dapat disimpulkan bahwa aktivitas organisasi RT/RW dengan masyarakat dan pemerintah kelurahan Rintis berjalan cukup baik. Ini terbukti dengan ikut aktif dan berpartisipasinya masyarakat dalam semua kegiatan yang dilakukan oleh RT/RW dan pemerintah kelurahan.

\section{Faktor Penghambat Penguatan Kelembagaan RT/RW}

Faktor yang menjadi hambatan dalam penguatan RT/RW dikelurahan Rintis seperti yang telah dijelaskan diatas adalah terkait dengan keterbatasan mendapatkan sumber daya manusia (SDM) yang mumpuni dan cakap untuk mengelola organisasi RT/RT, stuktur organisasi kurang berfungsi sehingga mempengaruhi tugas-tugas RT/RW sebagai mitra kerja pemerintah kelurahan, komitmen dan perhatian pemerintah daerah yang masih rendah terhadap keberadaan RT/RW. Dari beberapa faktor diatas dapat dijadikan sebagai bahan masukan dalam penguatan kelembagaan RT/RW di kelurahan Rintis Kecamatan lima puluh kota Pekanbaru.

\section{SIMPULAN}

Berdasarkan pembahasan yang telah diuraikan tentang penguatan kelembagaan RT/RW maka dapat diambil kesimpulan diantaranya:

1. Sumber daya manusia (SDM) yang akan dipilih menjadi RT/RW kelurahan Rintis masih mengalami kendala. Ini dikarenakan masyarakat kurang antusias untuk di-calonkan menjadi ketua RT/RW.

2. Struktur organisai RT/RW yang ada di kelurahan Rintis juga ada masalah yaitu masih belum berfungsinya kepengurusan RT/RW. Dalam hal ini masih banyak RT/RW yang bekerja sendirian tanpa dibantu oleh pengurus lainnya. Padahal fungsi dari struktur organisasi adalah adanya kejelasan tugas dan tanggungjawab dari setiap anggota organisasi sehingga organisasi dapat menjalankan fungsinya dengan baik.

3. Dari segi jaringan kerja (network) organisasi RT/RW baik dilihat dari koordinasi dan aktivitas organisasi sudah berjalan dengan baik. Hal ini sangat membantu pemerintah kelurahan didalam menjalankan program dan kegiatan pemerintah ditengah-tengah masyarakat. RT/RW 
sudah dapat menjadi jembatan antara kepentingan pemerintah dan masyarakat dengan cara menciptakan kegiatankegiatan yang langsung berkaitan dengan kepentingan masyarakat.

\section{DAFTAR PUSTAKA}

Hadari, Nawawi. 2005. Metode Penelitian Bidang Sosial. ed. Gadjah Mada University Press. Yogyakarta.

Ivancevich, John M Matteson, Michael T Konopaske, Robert. 2013. Organizational Organizational Behavior and Management Tenth Edition Organizational Organi-zational Behavior and Management. www. mhhe.com.

Kurniyati, Yuli. 2013. "Penguatan Kapasitas Kelembagaan Kelompok PEW Untuk Pengembangan Ekonomi Lokal Kota Yogyakarta.” Jurnal Maksipreneur: Manajemen, Koperasi, dan Entrepreneurship 3(1): 91.

Lexy J Moleong. 2010. Metodologi Penelitian Kualitatif. ed. PT. Remaja Rosdakarya. Bandung.

Moekijat. 2016. Perencanaan Sumber Daya Manusia. ed. Mandar Maju. Bandung.

Moenir, H.A.S. 2010. 2010. Manajemen Pelyanan Umum Di Indonesia. Jakarta: Bumi Aksara. Mungin,. ed. Bumi Aksara. jakarta.

Mutiarin, Dyah. 2014. Mutiarin, Dyah Dan Arif Zaenudin,Ed. 2014. Manajemen Birokrasi Dan Kebikajan, Penelusuran Konsep Dan Teori. Yogyakarta: Pustaka Pelajar. ed. Pustaka Pelajar. Yogyakarta.

Nasdian, Fredian Tony. 2005. Pengembangan Kelembagaan Dan Modal Sosial. ed.
Fakultas Pertanian dan Program Pascasarjana IPB. Bogor.

Osborne, David. 2007. Reinventing Government: What a Difference a Strategy Makes.

Pekanbaru, BPS Kota. 2018. BPS Kota Pekanbaru Dalam Angka. ed. BPS Kota Pekanbaru. Pekanbaru.

Pemerintah. 1999. UU No. 22. Indonesia: Pemerintah.

- 2004. UU No 32. Indonesia: Pemerintah.

2001. Kepres No. 49. ed. Pemerintah. Indonesia.

- 2007. PP No 41. Indonesia:

Pemerintah Kota. 2002. PERWAKO No 12. Pekanbaru: Pemerintah Kota Pekanbaru.

2016. PERWAKO No 64. Pekanbaru: Pemerintah Kota Pekanbaru.

Robbins, SP. 2011. Perilaku Organisasi. 1st ed. ed. Salemba Empat. jakarta.

Suhendri, Suhendri, and Eko Priyo Purnomo. 2017. "Penguatan Kelembagaan Dalam Pencegahan Dan Pengendalian Kebakaran Hutan Dan Lahan Di Kabupaten Muaro Jambi Provinsi Jambi." Journal of Governance and Public Policy 4(1): 174204.

Sumpeno. 2002. Capacity Building, Persiapan Dan Perencanaan. ed. Catholic Relief Services. jakarta.

Yanuardi. 2015. "Pelaksanaan Tugas Rukun Tetangga Dan Rukun Warga (RT/RW) Kelurahan Delima Pekanbaru." Administrasi Publik 2(2): 1-13. 